\author{
Robert Wiluś \\ Uniwersytet Łódzki \\ Katedra Geografii Miast i Turyzmu \\ 90-142 Łódź, ul. Kopcińskiego 31 \\ robwil@geo.uni.lodz.pl
}

\section{NADRZECZNA PRZESTRZEŃ TURYSTYCZNA}

\section{RIVER VALLEY TOURISM SPACE}

\begin{abstract}
Zarys treści: Współczesna turystyka szczególnie mocno związana jest $z$ obszarami wodnymi. Woda jest bowiem jednym $z$ najbardziej popularnych walorów turystycznych. Turystyka na obszarach wodnych tworzy przestrzeń turystyczna, której zakres, struktura oraz wielkość zależą przede wszystkim od stopnia dostępności do wody oraz możliwości jej wykorzystania do celów turystycznych. Rzeki są jednymi z mniej wykorzystywanych przez turystykę obszarów wodnych w porównaniu np. do mórz czy jezior. W artykule zaprezentowano przede wszystkim zależności rozwoju turystyki od specyfiki układu, jaki tworzy rzeka i jej dolina, które prowadzą do powstania nadrzecznej przestrzeni turystycznej. Nadrzeczna przestrzeń turystyczna jest zróżnicowana zarówno wewnętrznie wzdłuż biegu rzeki, jak i w profilu poprzecznym doliny rzecznej.
\end{abstract}

Słowa kluczowe: przestrzeń turystyczna, nadrzeczna przestrzeń turystyczna, rzeka, dolina rzeki.

Turystyka zarówno dawniej, jak i obecnie jest szczególnie związana $\mathrm{z}$ woda. Woda jest jednym Z najbardziej atrakcyjnych elementów środowiska przyrodniczego dla turystyki. To jeden z najpopularniejszych i podstawowych walorów turystycznych decydujących o atrakcyjności turystycznej obszaru znacznie wpływający na podniesienie jakości produktu turystycznego (WĄSOWICZ 2004, KOŻUCHOWSKI 2005). Do obszarów wodnych na świecie zalicza się morza, jeziora i stawy, rzeki, kanały i drogi wodne, tereny podmokłe. Każde z wymienionych środowisk wodnych oferuje inne możliwości rozwoju turystyki związanej z woda. Do najbardziej rozwiniętych pod względem turystycznym zalicza się tereny nadmorskie. Turystyka nadmorska należy także do najbardziej typowych form współczesnej turystyki wypoczynkowej, a tereny położone nad morzami należą do najintensywniej zagospodarowanych turystycznie obszarów na świecie. Ze względu na stałą dużą popularność turystyki nadmorskiej najwięcej uwagi poświęca się jej w różnego rodzaju
Abstract: Contemporary tourism is strongly related to water areas as water is one of the most popular tourism assets. Tourism in water areas creates a tourism space whose extent, structure and size depend mostly on access to water and the possibility of using it for tourism. Compared to seas or lakes, rivers are water areas not heavily exploited by tourism. The article presents the relation between tourism development and the particular river-valley system which creates river valley tourism space. This space is diversified both along the river and in the cross-section of the valley.

Key words: tourism space, river valley tourism space, river, river valley.

Tourism has always been closely connected to water as water is one of the most attractive elements of the natural environment from the tourist's point of view. It is one of the most popular and basic tourism assets which make an area attractive, greatly enhancing the quality of the tourism product (WASOWICZ 2004, KożUCHOWSKI 2005). Globally water areas include seas, lakes and ponds, rivers, their channels and canals, as well as marshes and each of these environments creates different opportunities for tourism development. Coastal areas are the most developed in this respect and coastal tourism is one of the most common forms of contemporary leisure. Due to its popularity a lot of attention has been devoted to it in a variety of research and publications whereas rivers and lakes, as well as other water areas are less exploited 
badaniach naukowych i publikacjach. Rzeki i jeziora, a także pozostałe rodzaje obszarów wodnych, w porównaniu z morzami są mniej wykorzystywanym środowiskiem wodnym przez turystykę. Stąd także poświęca się im mniej uwagi w badaniach nad turystyką (SMITH 2003).

Obszary wodne są częścią krajobrazu. Do szczególnie atrakcyjnych turystycznie zalicza się krajobrazy kontrastowe, związane ze strefą kontaktu wody z lądem, dające wiele możliwości rozwoju rekreacji (SOŁOWIEJ 1992, TUOHINo 2003). Rozwój turystyki na obszarach wodnych prowadzi do powstania specyficznego rodzaju przestrzeni turystycznej, której zakres, wielkość i charakter zależą nie tylko od stopnia atrakcyjności turystycznej wody i terenów ją otaczających, ale i od uwarunkowań fizycznogeograficznych, społecznych i gospodarczych wykreowanych przez wodę. Celem opracowania jest próba określenia przestrzeni turystycznej związanej z rzeką, jej zakresu, struktury oraz zróżnicowania.

\section{PRZESTRZEŃ DOLINY RZECZNEJ A TURYSTYKA (PRZESTRZEŃ TURYSTYCZNA)}

Rzeka jest przede wszystkim elementem środowiska naturalnego. Wraz z doliną tworzy odrębną i specyficzną pod względem przyrodniczym (fizycznogeograficznym) wyraźnie wyodrębnioną przestrzeń, stanowiącą część przestrzeni geograficznej. Jest ona wynikiem różnego rodzaju procesów przyrodniczych zachodzących w dolinie rzeki, a także i częściowo poza jej obrębem, w których uczestniczy rzeka jako najważniejszy element kreujący dolinę. Procesy te prowadzą do wyraźnego zróżnicowania przestrzeni przyrodniczej (fizycznogeograficznej) doliny rzecznej. Każda dolina rzeczna w przekroju poprzecznym składa się z dna, w którym znajduje się koryto rzeki i terasa zalewowa, ze stoków wraz z terasami, krawędzi i wysoczyzny. Dolina rzeczna jest również zróżnicowana wzdłuż jej biegu. Pod tym względem w skład doliny rzecznej wchodzą obszary źródliskowe, górnego, środkowego i dolnego biegu oraz ujścia rzeki. Specyfika zróżnicowania przestrzeni doliny rzecznej polega na tym, że rzeka oddziela dwa podobne jakościowo obszary i zarazem łączy poszczególne części doliny wzdłuż jej biegu. Całość tworzy zwarty i wyróżniający się układ fizycznogeograficzny o charakterze pasmowym, składający się z elementów liniowych, powierzchniowych i punktowych wzajemnie powiazanych (DROBEK 1996). Rzeka jest czynnikiem spraw- by tourism than the sea, and they are not studied so extensively (SMITH 2003).

Water areas are part of the landscape and contrastive landscapes, where water meets land, are considered to be particularly attractive as they offer a lot of recreational possibilities (SOlOwIEJ 1992, TuOHINo 2003). Tourism development in water areas leads to the creation of a particular tourism space, whose extent, size and character depend not only on how attractive the water and the surrounding area are, but also on the geographical, social and economic conditions created by the water. The aim of the article is to define river valley tourism space, its variety and structure.

\section{RIVER VALLEY SPACE AND TOURISM (TOURISM SPACE)}

The river is above all an element of the natural environment and, together with its valley, it creates a separate, naturally distinctive space, a part of geographical space. This is the outcome of various natural processes taking place in and partly outside the river valley with the river as the most significant element, processes which lead to a clear diversification of the valley's natural space. In crosssection each river valley consists of the river channel with a floodplain, slopes with terraces, valley edges and the surrounding higher land. The valley is also diversified longitudinally. In this respect the river valley comprises the source area, the areas of the upper, middle and lower courses of the river, and the mouth. The special character of river diversity lies in the fact that the river separates two similar areas and at the same time joins individual parts of the valley along its course. The result is a compact, distinctive geographical configuration, consisting of interlinked linear, surface and point elements (DROBEK 1996). The river is the causative factor of this system and its axis at the same time.

Rivers occur in practically all landscape zones in the world. Regardless of geographical location, the geographical system of the river valley remains largely 
czym tego układu i zarazem jego osią. Ma decydujący wplyw na jego funkcjonowanie.

Rzeki związane są praktycznie ze wszystkimi strefami krajobrazowymi na świecie. Niezależnie od położenia geograficznego układ fizycznogeograficzny doliny rzecznej pod względem fizjonomicznym pozostaje taki sam. Zmienne są natomiast elementy tworzące strukturę tego układu. Podlegaja one ciaglym procesom kształtowania przez rzekę. Fakt ten świadczy o tym, że przestrzeń fizycznogeograficzna doliny rzeki podlega zmianom. Jedną $z$ cech przestrzeni fizycznogeograficznej związanej z rzeką jest jej zakres. Praktycznie przestrzeń, która tworzy rzeka sięga dotąd, dokąd występują efekty procesów przyrodniczych zachodzących pod wplywem rzeki. Granice tej przestrzeni nie wykraczaja poza obręb doliny rzecznej, z wyjątkiem nietypowych sytuacji, takich jak np. powódź.

Rzeki wraz z dolinami to nie tylko część środowiska naturalnego. Rzeka ma ogromny wpływ na działalność i życie człowieka. Stała się ważnym elementem życia człowieka. W typowy, swoisty sposób była przez niego wykorzystywana (JAŁOWIECKI 1998). W historii rzeki odegrały istotną rolę w rozwoju wielu kultur i cywilizacji (PISKOzUB 2001). Były znaczącymi szlakami komunikacyjny$\mathrm{mi}$, arteriami rozwoju osadnictwa i gospodarczego. Czy zatem można mówić o przestrzeni doliny rzecznej z punktu widzenia występujących na jej obszarze elementów antropogenicznych?

W wyniku pelnionych przez rzekę różnorodnych funkcji wytworzył się w obrębie doliny specyficzny układ różnego rodzaju interakcji (związków) człowiek-rzeka, które doprowadzily do poWstania przestrzeni kulturowej rzeki (DROBEK 1993, 1996, NoBIS 1996). Wzajemne relacje pomiędzy czlowiekiem a rzeką nadały także wymiar społeczny tej przestrzeni. Pod tym względem rzeki stały się częścią przestrzeni społecznej (SZCZEPAŃSKI 1993, JALOWIECKI 1998). Warto zaznaczyć, że w obu przypadkach autorzy nazywaja określone przez siebie układy przestrzenią społeczną czy kulturową rzeki, a nie doliny rzecznej. W ten sposób podkreślają fakt, że to rzeka ma decydujący wpływ na kształtowanie przestrzeni z nią związanych. Wpływa bowiem na ludzkie postawy i opinie o niej samej, o problemach jej zagospodarowania oraz wykorzystania dawniej i obecnie, wyznaczając kręgi zainteresowań i interakcji między ludźmi, którzy nad nią żyli i pracowali (JACHER 1993). Podobnie jak było w przypadku przestrzeni fizycznogeograficznej doliny rzecznej, przestrzeń społeczna czy kulturowa związana z rzeką unchanged as far as physiognomy is concerned. However, the elements of this system undergo constant change, meaning that the geographical space of the river valley also changes. One of the parameters of river-related geographical space is its extent, as in practice it reaches as far as it is possible to observe the effects of natural processes caused by the river. The boundaries of this space do not exceed the river basin.

Rivers and valleys are not merely parts of the natural environment, they have an immense influence on human activity and have become an important element of human life. Exploited in specific ways (JAKOWIECKI 1998), rivers have played an important role in the development of many cultures and civilizations (PISKOZUB 2001), formed important routes, and arteries of settlement and economic develop-ment. Can river valley space then be looked on from the perspective of its anthropogenic elements?

As a result of the different functions performed by a river a particular system of interactions between man and the river within its valley appeared which led to the emergence of a cultural river space (DROBEK 1993, 1996, NoBIS 1996). The mutual relation between man and river gave this space a social dimension as well and in this respect rivers have become a part of social space (SZCZEPAŃSKI 1993, JAŁOWIECKI 1998). It is worth noticing that both authors call the system a social or cultural space, not river valley space, and in this way emphasize the fact that the river determines the spaces related to it. It influences human attitudes and opinions, problems of development and exploitation in the past, and at present, by inspiring interests and interaction among the people who live and work near it (JACHER 1993). Similar to the geographical space of the river valley, social or cultural space is also diversified and changes over time. This diversity depends on the possible ways of exploiting the river which as a result changes physically, chemically and biologically, as well as acquiring a cultural dimension (KORTELAINEN 1999). Change over time is associated with the changing role and importance of rivers in the lives of individuals and whole societies. Rivers are very useful to man. 
jest także zróżnicowana i zmienna w czasie. Stopień jej zróżnicowania zależy od możliwości oraz sposobu wykorzystania rzeki przez człowieka, który zmienia rzekę fizycznie, chemicznie i biologicznie, a także nadaje jej kulturowy sens (KORTELAINEN 1999). Zmienność w czasie wiąże się ze zmianą roli i znaczenia rzek w życiu człowieka i społeczeństw. Rzeki przysparzają wielu korzyści człowiekowi. Oprócz dostarczania wody pitnej, dla przemysłu i rolnictwa, pelnienia funkcji transportowych, energetycznych, coraz większą rolę przypisuje się rzekom w rozwoju turystyki i rekreacji (LOOMIS i in. 2000).

Od wielu już lat obserwuje się zmniejszenie rangi potencjahu gospodarczego rzek. Dotyczy to zwłaszcza transportu wodnego. Na przykład kanały, uregulowane rzeki, które powstały w wyniku zwiększonego zapotrzebowania na transport wodny w XIX w. w Wielkiej Brytanii, dziś wykorzystywane są jako atrakcyjne szlaki wodne i postrzegane jako oazy spokoju i wypoczynku (CLARKE 1996). Podobnie jest w przypadku znanych w Polsce kanałów - Augustowskiego i Elbląskiego, które same w sobie są atrakcjami turystycznymi (FURGAŁA-SELEZNIOW i in., 2003). Także duże uregulowane rzeki zaczynają być coraz częściej postrzegane jako atrakcyjne miejsca dla rozwoju turystyki i rekreacji, np. Odra (LISZEWSKI, red. 2003), Rodan (DEWAILLY i in. 2005), Ren (LAZZAROTTI 2002), Loara (WĘCLAWOWICZ-BILSKA 1993, CHURSKI 1998). Wzrost znaczenia rzek dla turystyki wiąże się także z poprawą stanu środowiska naturalnego, zwłaszcza jakości wody, najważniejszego jej waloru turystycznego (TUOHINO 2003). Wraz z krajobrazem i dostępnością brzegów woda stanowi o wartości rzeki dla turystyki. Niemniej o atrakcyjności turystycznej rzeki decyduje wiele innych elementów. Zdaniem STEINBACHA (1995), atrakcyjność turystyczna rzek wynika z:

- wartości estetycznych krajobrazu zdeterminowanego przez kombinacje niezwykłych połączeń obiektów przyrodniczych i elementów dziedzictwa kulturowego, postrzeganych przez wielu obserwatorów jako harmonijne;

- istnienia wielu miejscowości wypoczynkowych (stacji) położonych wzdłuż rzeki, będących celem specyficznych zainteresowań turystów;

- możliwości wykorzystania transportu niezanieczyszczającego rzeki i jej otoczenia - łodzie, rowery itp.

Podobnie atrakcyjność turystyczną rzek postrzega WYRZYKOWSKI (1994), który wyróżnił takie cechy, jak:
Apart from supplying domestic water, water for industry and agriculture, and performing transport and energy-generating functions, rivers play a growing part in tourism and recreation development.

The importance of rivers economically has been decreasing for many years. This mainly concerns water transport where canals and regulated rivers which appeared as a result of the high demand for water transport in the early $19^{\text {th }}$ c. in Great Britain, are used today as attractive water routes and perceived as oases of peace and recreation (CLARKE 1996). This is similar to the case of the famous Polish canals Augustowski and Elblaski, tourist attractions in themselves (AFURGALA-SELEZNIOW et al., 2003). Large regulated rivers are also beginning to be perceived as attractive sites for tourism and recreation development, e.g. the Odra (LISZEWSKI, ed. 2003), the Rhone (DEWAILly et al. 2005), the Rhine (LAZZAROTTI 2002), and the Loire (WECŁAWOWICZBILSKA 1993, CHURSKI 1998). The growing tourism importance of rivers is connected with the improved condition of the natural environment, and especially the most important tourism asset water quality (TUOHINo 2003). However, the attractiveness of a river is determined by many other factors and the key factor in river valley tourism development is the water itself which, combined with the landscape and access to the banks, makes a river so valuable. According to STEIBACH (1995), the tourist attractiveness of rivers comes from the following:

- aesthetic landscape assets, unusual combinations of natural and cultural elements, perceived by many as harmonious,

- the location of many tourism destinations along the river catering for tourists' special interests,

- the possibility of using transport which does not pollute the river and the surrounding area - boats, bicycles, etc.

The tourism attractiveness of rivers is seen in a similar way by WYRZYKOWSKI (1994) who distinguished the following features:

- aesthetic landscape assets,

- the possibility of bathing in the river and taking part in water sports, 
- walory estetyczne i widokowe krajobrazu;

- możliwości kapieli i uprawiania sportów oraz "wędrówek" wodnych;

- czyste powietrze, cisza, spokój, niski stopień urbanizacji i brak przeciwwskazań klimatycznych (cechy niezbędne) oraz szczególnie korzystne warunki bioklimatyczne (cechy korzystne);

- głębokość rzeki i czystość wody, charakter brzegów (dostępność od strony lądu i wody), stopień rozczłonkowania linii brzegowej;

- użytkowanie strefy przybrzeżnej (w tym występowanie i cechy użytkowe obszarów leśnych), występowanie walorów krajoznawczych;

- przydatność dla form specjalistycznych (żeglarstwo, wędkarstwo), możliwość spływów kajakowych, motorowych i turystycznej żeglugi pasażerskiej.

Dość szczegółowo kryteria oceny przydatności turystycznej rzek określił także SEWERNIAK (2002). Wśród wielu precyzyjnie wyznaczonych parametrów wplywających na rozwój turystyki na rzece, wskazane zostały bardziej ogólne cechy krajobrazu doliny rzecznej decydujace o atrakcyjności turystycznej samej rzeki. Atrakcyjnością turystyczną dolin rzecznych zajmowali się również WILUŚ (1997) i WOJCIECHOWSKA (1998), którzy opisali przestrzeń turystyczną dolin największych rzek Polski środkowej - Warty i Pilicy.

Generalnie układ rzeki i jej doliny jest atrakcyjny turystycznie sam w sobie. Miara atrakcyjności turystycznej tego układu są elementy z jednej strony zwiazane bezpośrednio z rzeka, a $\mathrm{z}$ drugiej $\mathrm{z}$ jej otoczeniem. Podejście do przestrzeni doliny rzeki, jako zamkniętego i nierozerwalnego układu powiązań rzeki z lądem, w przypadku turystyki oznacza, że turystyka na rzece nie istniałaby bez tego, co znajduje się wokól niej. Wytworzona w ten sposób przestrzeń turystyczna jest wynikiem wzajemnych interakcji turysty i rzeki. Jest to wyróżniająca się pod względem funkcjonalnym część przestrzeni geograficznej doliny rzecznej. Rzeka jest najważniejszym elementem tej przestrzeni i ma decydujący wpływ na jej powstanie, zakres i strukturę.

\section{NADRZECZNA PRZESTRZEŃ TURYSTYCZNA (ZALOŻENIA)}

Przestrzeń turystyczna stanowi jeden z podstawowych przedmiotów badań geografii turyzmu (WARSZYŃSKA, JACKOWSKI 1978, STALSKI 1984, STACHOWSKI 1993, LISZEWSKI 1995, LISZEWSKI, BACZWAROW 1998). Prowadzone przez geografów bada-
- clean air, peace and quiet, low urbanization with no unfavourable climatic condiOtions (necessary feature), particularly good bioclimatic conditions (beneficial feature),

- the depth and cleanness of the water, type of bank (accessibility from land and water), variability of river banks

- exploitation of the riverside (including forested areas), tourism assets,

- usefulness for particular purposes (sailing, fishing), opportunities for canoeing and motor boating, as well as tourist passenger services

The criteria for evaluating the tourism usefulness of rivers have been also defined in detail by SEWERNIAK (2003). Among many precise parameters of tourism development, he pointed to the general characteristics of the river basin landscape which determine the tourism attractiveness of the river itself. This tourism attractiveness has also been studied by WILUŚ (1997) and WOJCIECHOWSKA (1998) who described the tourism space of the Warta and Pilica valleys (the largest rivers in central Poland).

Generally speaking, the river-valley system is attractive in itself. Measures of tourism attractiveness are elements on the one hand directly connected with the river, and on the other - with its surroundings. Seeing river valley space as a closed and stable set of relations between the river and the land means that tourism on the river would not exist without that relation. The tourism space so created is a result of the interaction between the tourist and the river, a functionally distinctive part of the geographical space of the river valley with the river as the most important element of this space, determining its extent and structure.

\section{RIVER VALLEY TOURISM SPACE - ASSUMPTIONS}

Tourism space is one of the basic research areas in tourism geography (WARSZYŃSKA \& JACKOWSKI 1978, STALSKI 1984, STACHOWSKI 1993, LISZEWSKI 1995, LISZEWSKI \& BACZWAROW 1998) but studies 
nia nad przestrzenią turystyczną miały głównie charakter teoretyczny, w mniejszym stopniu zaś empiryczny (STACHOWSKI 1993). Obecnie można stwierdzić, że po wypracowaniu wielu teoretycznych koncepcji, główny nurt badawczy związany z przestrzenią turystyczną kieruje się coraz bardziej w stronę badań empirycznych weryfikujących wcześniejsze koncepcje teoretyczne (WILUŚ 1997, WOJCIECHOWSKA 1998, LISZEWSKI 1999, WŁODARCZYK 1999).

Przystępując do określenia przestrzeni turystycznej doliny rzecznej należy dokonać wyboru koncepcji ogólnej, najbardziej odpowiedniej do opisania efektów wzajemnych interakcji turysty i rzeki. $\mathrm{Z}$ jednej strony mamy do czynienia $\mathrm{z}$ funkcjonowaniem - najogólniej mówiąc - skomplikowanego systemu różnorodnych procesów przyrodniczych, w których uczestniczy rzeka i które tworzą wyróżniający się $w$ krajobrazie typ przestrzeni fizycznogeograficznej. $Z$ drugiej strony przestrzeń ta jest wykorzystywana przez człowieka w stopniu, na jaki pozwala mu rzeka i utworzona przez nią dolina. Zatem $w$ przestrzeni doliny rzeki mamy do czynienia z efektami działalności natury i człowieka, a rzeka w szczególny sposób łączy te wartości. Turystyka wpisuje się w ogólną przestrzeń geograficzną doliny rzeki.

Podobnie jak w przypadku innych form działalności człowieka związanych z rzeką, rozwój turystyki uzależniony jest przede wszystkim od warunków przyrodniczych występujących w dolinie. Rzeka stanowi najważniejszy walor przyrodniczy doliny. Jest czynnikiem sprawczym wielu zjawisk społecznych, w tym również turystyki. Ma także decydujący wpływ na rozwiązania funkcjonalno-przestrzenne związane z turystyka. Specyficzny układ fizycznogeograficzny doliny rzeki rzutuje bowiem na rozmieszczenie zagospodarowania turystycznego. Najważniejszym czynnikiem jego lokalizacji jest dostęp do wody i odległość od niej, podobnie jak w przypadku pozostałych obszarów wodnych. Atrakcyjność krajobrazu dolin rzecznych wpływa także na rozwój swoistych form turystyki: turystyki związanej z rzeką (STEINBACH 1995) oraz z jej otoczeniem. Doliny rzeczne to zarówno atrakcyjne szlaki turystyki wodnej, jak i lądowej (pieszej, rowerowej, konnej itp.). Popularność wędrówek turystycznych wzdłuż brzegów rzeki czy przemieszczania się jej wodami (kajakiem, żaglówką, statkiem itp.) wynika głównie z możliwości korzystania z czynnego wypoczynku oraz obserwowania ciaggłej zmiany krajobrazu.

Walory przyrodnicze rzek i ich dolin sa atrakcyjne dla rozwoju różnych przestrzennie form rekre- of tourism space have been mainly theoretical rather than empirical (STACHOWSKI 1993). At present numerous theoretical ideas are being followed up by empirical studies of tourism space to examine earlier assumptions (WILUŚ 1997, WOJCIECHOWSKA 1998, LISZEWSKI 1999, WŁODARCZYK 1999).

In order to define the tourism space of the river valley, it is necessary to choose a general idea which would most suitably describe the effects of the touristriver interaction. On the one hand there is the complicated system of a variety of natural processes involving the river creating a distinctive type of geographical space. On the other the space is exploited by man as much as the river and its valley allow. Therefore, the effects of both natural and human activity in river valley space are found, and the river is the link. Tourism is a component of the general geographical space of the river valley.

Similar to other forms of human waterrelated activity, the development of tourism depends mostly on the natural conditions in the valley. The river is the main natural asset and the cause of many social phenomena including tourism. It also imposes functionalspatial solutions connected with tourism and the specific geographical system of the river valley affects the distribution of the tourism infrastructure. The most important location factor is access to water or distance from it, like other water areas and the attractiveness of the river landscape conditions the development of particular forms of water-related tourism (STEINBACH 1995). River valleys are attractive water and land tourism routes (walking, cycling, horse-riding, etc.) while the popularity of moving along river banks or on the water (by canoe, sailing boat, ship, etc.) comes from opportunities for active recreation and observing the changing landscape.

The natural assets of rivers and their valleys trigger the development of spatially different forms of recreation: surface (holidays), linear (canoeing and sailing) and point (e.g. fishing) recreation. 
acji: powierzchniowej (turystyka wypoczynkowa pobytowa), liniowej (splywy kajakowe, żeglarskie itd.) i punktowej (np. wędkarstwo).

Funkcjonowanie układu rzeka-dolina prowadzi do powstania specyficznej przestrzeni, której istota są wzajemne interakcje elementów tworzących ten układ. Na przestrzeń ogólną doliny rzeki - jak wspomniano - składają się elementy przyrodnicze i efekty działalności człowieka związane z rzeką. Czlowiek - turysta, wykorzystując przestrzeń rzeki i jej doliny do celów turystycznych i wypoczynkowych, wchodzi w rozmaite relacje $\mathrm{z}$ tymi elementami i w ten sposób przyczynia się do powstania przestrzeni turystycznej. Do opisania wszelkich przejawów turystyki na terenie doliny rzecznej, z uwzględnieniem specyfiki jej układu, wybrano koncepcję przestrzeni turystycznej LISZEWSKIEGO (1995). Według tego autora, przestrzeń turystyczna jest „funkcjonalnie wyróżniającą się podprzestrzenią przestrzeni geograficznej rozumianej w sensie largo, tzn. jako przestrzeń, na którą składają się elementy przyrodnicze powłoki Ziemi (środowisko naturalne), trwałe efekty działalności ludzkiej W tym środowisku (środowisko gospodarcze), a także środowisko społeczne". Definicja ta ujmuje całościowo sferę turystyczną (LISZEWSKI, BACZWAROW 1998), a także zwraca uwagę na efekty wzajemnych interakcji pomiędzy człowiekiem turystą a szeroko rozumianym środowiskiem miejsca odwiedzanego. Skala, charakter i zakres tych efektów odzwierciedla funkcjonalny podział przestrzeni turystycznej na pięć typów. Są to przestrzenie: eksploracji, penetracji, asymilacji, kolonizacji i urbanizacji turystycznej, które pokazują stopień wykorzystania ogólnej przestrzeni geograficznej przez turystykę.

Układ przyrodniczy rzeki i jej doliny praktycznie będzie warunkowal powstanie, rozmieszczenie i zakres poszczególnych typów przestrzeni turystycznej. Przestrzeń turystyczna, która powstała w wyniku wzajemnych interakcji człowieka turysty i rzeki, nie zawsze ogranicza się tylko do formalnych przyrodniczych granic doliny, którymi są jej krawędzie. Turystyka związana $\mathrm{z}$ rzekami i ich dolinami rozwija się także na wysoczyźnie, położonej poza doliną. Całą tę analizowaną przestrzeń turystyczną doliny rzecznej proponuję nazwać nadrzeczną przestrzenią turystyczną.

Nadrzeczna przestrzeń turystyczna zróżnicowana jest zarówno wzdłuż, jak i wszerz doliny rzecznej. Rozmieszczenie poszczególnych typów przestrzeni turystycznej rozpoczniemy od przeprowadzenia analizy wzdłuż doliny rzecznej. Początek rzeki, czyli obszary źródliskowe zajmują na ogół niewielką po-
The functioning of the river-valley system leads to the creation of a special type of space, based on the interaction between system constituents. The general space of the valley consists of natural elements and the effects of human activity, and by using the space of the river and the valley for tourism and recreation man interacts with it and in this way contributes to the creation of the tourism space. In order to describe all the 'symptoms' of tourism in the river valley, and considering the special character of the system, the author chose the concept of tourism space proposed by LISZEWSKI (1995). This concept is based on the assumption that tourism space is 'a functionally distinctive sub-space of geographical space in the wider sense of the word i.e. a space which includes natural elements of the Earth's surface (natural environment), permanent effects of human activity in this environment (economic environment), as well as the social environment'. The definition refers to the whole tourism domain (LiszewsKI \& BACZWAROW 1998), as well as focusing on the effects of the interaction between man the tourist and the environment of the visited site. The scale, character and extent of these effects reflect the functional division of tourism space into five types: tourism exploration, penetration, assimilation, colonization and urbanization spaces, each of which shows the exploitation of general geographical space by tourism.

The natural river valley system will in practice determine the creation, distribution and extent of the individual types of tourism space. The tourism space which has resulted from the interaction between man and the river is not always limited to the formal natural borders of the valley, as river and valley tourism also develop on uplands surrounding the valley. I suggest that this tourism space be called 'river valley tourism space'.

River valley tourism space is diversified both along and across the valley and the analysis will begin from the distribution of individual types of tourism 
wierzchnię. Charakteryzują się ograniczoną dostępnością i zwykle brakiem zagospodarowania ze względu na ochronę środowiska ${ }^{1}$. Cechą źródeł rzek jest także ich trudna dostępność i dość często ukrycie. Atrakcyjność turystyczna początkowego fragmentu rzeki wynika $\mathrm{z}$ walorów przyrodniczych o charakterze poznawczym, a po części ze świadomości emocji, jakich dostarcza fakt przebywania w miejscu, gdzie „coś” istotnego się rozpoczyna. Ze względu na specyficzny charakter tych miejsc, odwiedzane są one przez niewielu turystów. $\mathrm{Z}$ punktu widzenia ujęcia przestrzennego turystyka u źródel rzeki ma charakter punktowy. Wymienione cechy obszarów źródliskowych predestynują je głównie do rozwoju przestrzeni eksploracji turystycznej. Przykładami mogą tu być źródła znanych rzek Polski np. Wisły na Baraniej Górze czy Warty w Kromołowie na Jurze Polskiej. Na świecie najbardziej spektakularne pod tym względem są źródła Amazonki czy Nilu, dokąd ciaggle docierają nieliczni turyści.

$\mathrm{Na}$ obszarze górnego biegu rzeki dolina jest wąska i głęboko wcięta. Rzeka płynie całą szerokością koryta i charakteryzuje się dość znacznym spadkiem. Doliny w odcinkach górnego biegu rzeki przybierają wyraziste kształty. Zbocza dolin są na ogół dość strome i wysokie, a krawędzie wyraźnie zarysowane w krajobrazie. Krajobraz doliny w górnym odcinku jest wynikiem wzmożonej erozji rzecznej prowadzącej także do powstawania przewężeń (przełomów). Jest on atrakcyjny przede wszystkim dla turystyki aktywnej związanej zarówno $z$ woda, jak i z lądem. Turystyczne walory przyrodnicze występujące w górnym odcinku doliny rzeki mają charakter poznawczy i specjalistyczny. Do najbardziej popularnych form turystyki aktywnej rozwijających się w górnych odcinkach dolin należa przede wszystkim różnego rodzaju spływy (kajakowe, tratwami czy pontonami, czyli tzw. rafting). Szybki nurt rzeki, niebezpieczne dno, trudno dostępny brzeg zmniejszają atrakcyjność górnego odcinka rzeki dla rozwoju popularnych form rekreacji związanej z wodą (kapiele). Duża atrakcyjność krajobrazowa dolin rzecznych $w$ analizowanym fragmencie sprzyja rozwojowi turystyki aktywnej w części lądowej. Należy tu wymienić głównie turystykę piesza. która rozwija się na wysoczyznach wzdłuż krawędzi, skąd można podziwiać krajobrazy przeciwleglych brzegów. Obszary górnego biegu rzek charakteryzują się dość trudnymi warunkami dla rozwoju wszelkich form zagospodarowania. Zagospodarowanie turystyczne występuje właściwie w strefie kontaktu wody z lądem i ogranicza się głównie do urządzeń umożliwiających uprawianie turystyki na rze- space along the valley. The beginning of the river, i.e. the source area, is usually small, access to it is limited and it is usually not developed for ecological reasons ${ }^{1}$. River sources are also difficult to trace. The tourism attractiveness of this area comes from the natural assets and partly from the emotional awareness that one is at the exact place where 'something' important begins. Due to the very special character of these places, they are visited by few tourists. The features described above mean source areas for the development of tourism exploration space - here are examples of some famous Polish rivers: the Vistula source on Barania Gora and the Warta in Kromolowo in the Polish Jura. Sources of such important rivers as the Amazon or the Nile are still visited by very few tourists.

In its upper section the river valley is often narrow and deep, the water covers the whole river bed and the gradient is considerable. The valley slopes are usually quite steep and high, the edges clearly standing out and the valley landscape is often the result of severe erosion which can also lead to the creation of ravines. It is attractive above all for active tourism on both water and land while the natural assets lend themselves to educational and active tourism (whose most popular forms are for instance canoeing or rafting). The fast current, dangerous river bed and inaccessible river banks decrease the attractiveness of the upper reaches of the river for such popular forms of water-related recreation as bathing. The high attractiveness of this section leads however to the development of active tourism on land with hiking on the surrounding uplands where the natural beauty of the other side of the valley can be seen. The areas in the upper part of the river are difficult to develop economically, in fact, development occurs only on the border of water and land and is limited to the infrastructure which enables river tourism for instance jetties and small piers. The valley slopes are not developed while 
ce - pomosty, niewielkie przystanie. Zbocza dolin pozostają niezagospodarowane. Trudne warunki morfologiczne nie sprzyjały w historii także rozwojowi osadnictwa na stokach doliny. Powstawały głównie punktowe formy osadnicze o charakterze obronnym, np. zamki, które dziś stanowią istotny walor turystyczny. Tak więc $w$ górnym biegu rzeki mamy do czynienia przede wszystkim z przestrzenia penetracji turystycznej. Przykładami moga tu być doliny rzek polskich, które swój początek biorą w górach, na czele z największą górską rzeka, Dunajcem. Na świecie do bardziej znanych przykładów nadrzecznej przestrzeni penetracji turystycznej związanej z górnymi odcinkami rzek można zaliczyć takie rzeki, jak Colorado w USA, Khali Gandhaki w Nepalu czy Nil na terenie Ugandy.

Górne odcinki rzek charakteryzują się także ingerencją człowieka w naturę rzeki. Najczęściej polega ona na wybudowaniu sztucznych zbiorników, które przeznaczone są w pierwszej kolejności do celów retencyjnych, a w następnej, energetycznych i rekreacyjnych ${ }^{2}$. Pojawienie się dużej, zwartej powierzchni wodnej w dość urozmaiconym pod względem rzeźby terenie zmienia radykalnie krajobraz doliny i sposób jej zagospodarowania. Uznając kwestię atrakcyjności turystycznej tego rodzaju inwestycji za rzecz względną i dyskusyjną, należy podkreślić, że sztuczne zbiorniki przyczyniają się do rozwoju turystyki. Łatwiejszy dostęp do wody z brzegu powoduje rozwój bardziej popularnych form wypoczynku nad wodą połączonego m.in. z kąpielami, jeżeli pozwala na to czystość wód ${ }^{3}$. To $z$ kolei wpływa na rozwój trwałego zagospodarowania turystycznego wokół zbiorników. Stąd, obok przestrzeni penetracji, pojawia się także przestrzeń kolonizacji turystycznej. Ponadto po wybudowaniu sztucznego zbiornika, jego linia brzegowa zbliża się często do granic miejscowości położonych już na wysoczyźnie, które zaczynają rozwijać funkcję turystyczną związaną ze zbiornikiem. Przykładem mogą być wsie położone wokół zbiornika czorsztyńskiego na Dunajcu, np. Niedzica, Czorsztyn, Kluszkowce, Sromowce. Tego rodzaju miejscowości stają się miejscem rozwoju przestrzeni asymilacji, którą wspóltworzą turyści i stali mieszkańcy. Z punktu widzenia roli rzeki w powstaniu nadrzecznej przestrzeni turystycznej można stwierdzić, że wraz z wybudowaniem sztucznego zbiornika rzeka traci w tym miejscu swój typowy charakter cieku i może przestać być postrzegana jako podstawowy walor turystyczny doliny na rzecz jeziora.

Wyróżniającym elementem krajobrazu dolin rzecznych są wodospady pojawiające się w miej- difficult morphological conditions prevent the development of settlement although there are individual defensive settlement forms, like castles, which are a significant tourism asset today. Thus, the upper reaches of the river form mainly a tourism penetration space (e.g. the mountain sources of the Dunajec in Poland or the Colorado River in the USA, Khali Gandhaki in Nepal or the Nile in Uganda).

Man interferes with the nature of the river in its upper parts, most often in the form of the building artificial reservoirs for water retention, hydroelectric plants or recreation-oriented infrastructure ${ }^{2}$. The appearance of a large compact water area in a varied terrain radically changes the valley landscape and the way it is developed. The tourism attractiveness of this sort of investment remains arguable, but it must be stressed that artificial reservoirs are conducive to tourism development. The easy access to water from the banks leads to the development of popular forms of water recreation, combined with bathing if the cleanness of the water permits $^{3}$. This in turn has influence on the development of a permanent tourism infrastructure around the reservoirs. Next to penetration space there is tourism colonization space. What is more, after a reservoir is built, its water level often comes close to the borders of settlements situated in the uplands which start to develop a tourism function connected with the reservoir. Good examples are the villages around the Czorsztyn reservoir on the Dunajec River, e.g. Niedzica, Czorsztyn, Kluszkowce or Sromowce, where assimilation space created by tourists and local inhabitants has developed. As far as the role the river plays in the creation of the river valley tourism space, it can be said that once an artificial reservoir is built, the river loses its typical character and the basic tourism asset of the valley becomes a lake.

One distinctive feature of a river valley landscape is a waterfall which will appear in places where the river 
scu występowania różnicy poziomów dna koryta rzeki; zwykle związane są z górnym biegiem rzek. Istnieje duża różnorodność wodospadów na świecie. Różnią się one wysokością, szerokością i liczbą strumieni oraz wyglądem progu. Wodospady są przede wszystkim dużą atrakcją poznawcza, dostarczają wielu doznań estetycznych. Ich charakter oraz atrakcyjność wpływa na rodzaj przestrzeni turystycznej, która powstaje wokół nich. Generalnie mamy tu do czynienia $\mathrm{z}$ przestrzenia penetracji turystycznej zarówno w części lądowej, jak i wodnej. Z kolei w przypadku najbardziej znanych wodospadów na świecie, duży ruch turystyczny przyczynia się do rozwoju stałego zagospodarowania turystycznego wokół wodospadów, a więc i przestrzeni kolonizacji turystycznej. Przykładem są tu słynne wodospady Niagara na granicy USA i Kanady czy Iguaçu na pograniczu Argentyny, Paragwaju i Brazylii, które uważane są za fenomeny przyrody. Wodospady mogą występować także w środkowym i dolnym biegu rzeki. Jednak ze względu na mniejsze nachylenie terenu oraz mniejszy spadek wody występuja rzadziej i nie są już tak spektakularnym zjawiskiem przyrodniczym.

Przemieszczając się w dół rzeki, następny w kolejności jest obszar środkowego jej biegu. $Z$ jednej strony różni się on od górnej i dolnej części doliny, ale $\mathrm{z}$ drugiej zawiera $\mathrm{w}$ sobie elementy krajobrazu przypominające na przemian o górnym i dolnym biegu. Krajobraz środkowego odcinka doliny rzecznej jest najbardziej zróżnicowany na całej jej długości. Różnorodność krajobrazowa dolin rzecznych w ich środkowym fragmencie sprzyja rozwojowi różnych form działalności człowieka związanych z wykorzystaniem rzeki i jej doliny. Dotyczy to m.in. osadnictwa, żeglugi, rolnictwa, a także turystyki i rekreacji. Rzeki płyną wolniej i znacznie szerszym korytem. Wolniejszy nurt sprzyja powstawaniu meandrów. Doliny są także szersze i płytsze, a brzegi niższe, mniej strome, miejscami z wyraźnie zaznaczonymi poziomami terasowymi. Rzeka i jej dolina nadal są atrakcyjne zarówno dla spływów wodnych, jak i wędrówek lądowych wzdłuż jej biegu dzięki zmienności krajobrazu ${ }^{4}$. W porównaniu z górnym biegiem zwiększa się także dostępność brzegów i wody, umożliwiając rozwój form rekreacji związanych z wodą i wypoczynkiem nadwodnym. Uwarunkowania fizycznogeograficzne doliny rzeki w środkowym odcinku bardziej sprzyjają rozwojowi trwałych form zagospodarowania turystycznego w obrębie doliny i nad samą rzeką. Tak więc środkowy odcinek doliny rzeki związany jest przede wszystkim $\mathrm{z}$ typem przestrzeni penetracji i koloniza- flows over a formation that forms a sudden break in elevation, usually in the upper part. There are a great variety of waterfalls in the world differing as regards height, width, the number of streams and the threshold. Waterfalls are extraordinary aesthetic attractions and their character and attractiveness have an influence on the type of the tourism space which is created around it. Generally speaking, these are tourism penetration spaces, both on water and land. As far as the most famous waterfalls in the world are concerned, heavy levels of tourism lead to the development of a permanent tourism infrastructure, and consequently - tourism colonization space (Niagara Falls on the border of the USA and Canada, or Iguacu on the borders of Argentina, Paraguay and Brazil - both considered natural wonders).

The middle reaches of the river differ from the upper and lower, but contain similar elements. This part of the river has the most varied landscape which helps the development of different forms of human activity connected with river and valley exploitation including settlement, navigation, agriculture, tourism and recreation. The river channel is much wider and meanders are formed, the valleys are wider and shallower, and the banks lower, less steep, with distinctive terraces. The river and its valley are still attractive both for water activities and hiking because of the changing landscape ${ }^{4}$. Compared to the upper reaches, the accessibility of the banks and water increases and water-related forms of recreation develop. The geographical conditions here are conducive to the development of a permanent tourism infrastructure within the valley and on the river itself. The middle section is then above all a tourism penetration and colonization space. Due to attractive conditions for settlement development, more towns and villages have appeared in the valley which leads to the development of tourism assimilation space. In a situation when the river flows through a town 
cji turystycznej. Z kolei pojawienie się $\mathrm{w}$ dolinie rzeki, dzięki atrakcyjnym warunkom dla rozwoju osadnictwa, większej liczby jednostek osadniczych (zarówno miast jak i wsi), wpływa na rozwój przestrzeni asymilacji turystycznej. W sytuacji, kiedy rzeka przepływa przez miasto lub wieś, staje się ona częścią przestrzeni osadniczej (miejskiej bądź wiejskiej), gdzie konkuruje $z$ innymi elementami tworzącymi tę przestrzeń. Stanowi tu także jeden z ważnych czynników determinujących układy architektoniczno-urbanistyczne (DRAPELLA-HERMANS-DORFER 1993). Obszary nadrzeczne miasta traktowane są dość często jako atrakcyjne fragmenty z punktu widzenia rozwoju turystyki i rekreacji. W przestrzeni miejskiej przepływająca rzeka ma wpływ na rozwój przestrzeni penetracji, a w niektórych przypadkach kolonizacji turystycznej. Obiekty trwałego zagospodarowania turystycznego związanego z wypoczynkiem w miastach lokują się najczęściej na atrakcyjnych przyrodniczo terenach położonych m.in. nad wodami (LISZEWSKI 1999).

W środkowych odcinkach niektórych rzek budowane są również sztuczne zbiorniki, które wywohuja zmiany $\mathrm{w}$ przestrzeni doliny rzeki i w jej podprzestrzeniach, podobne do opisywanych wcześniej W górnym odcinku. Cechą charakterystyczną tego typu akwenów są duże wahania wysokości lustra wody powodujące zmienność powierzchni wodnej i okresowe odsłanianie podmokłego dna, co czyni je mało atrakcyjnymi dla turystyki wypoczynkowej. Pomimo tych mankamentów spotyka się wiele przykładów tego rodzaju zbiorników, gdzie turystyka rozwija się nie tylko na wodzie, ale też i wokół zbiorników, głównie $\mathrm{z}$ powodu braku alternatywnych naturalnych akwenów. Można tutaj wymienić zbiorniki: Sulejowski na Pilicy, Jeziorsko na Warcie czy Włocławski na Wiśle. Duże wahania wysokości lustra wody prowadzą do powstania w strefach objętych ,,cofką" rozległych obszarów podmokłych, będących atrakcyjnym siedliskiem dla ptactwa wodnego. Przykładem może być zbiornik Jeziorsko; na obszarze „,cofki” utworzono strefę ciszy w' celu ochrony miejsc lęgowych ptaków wodnych. Tego rodzaju miejsca stają się coraz bardziej atrakcyjne ${ }^{2}$ poznawczego punktu widzenia. Można je uznać także jako przestrzeń eksploracji turystycznej.

Przedostatnim analizowanym pod kątem rozwoju nadrzecznej przestrzeni turystycznej fragmentem doliny jest odcinek dolnego biegu rzeki. Wyróżnia się on bardzo szeroką i płytką doliną o mało wyrazistej formie, płynnie przechodzącej w wysoczyznę. Rzeka na tym odcinku płynie dość obszernym i szerokim korytem. Spadek rzeki jest mały, a dostęp do or village, it becomes a part of the settlement space (urban or rural) where it competes with other spatial elements. It is also one of the factors determining the architectural system (DRAPELLAHERMANSDORFER 1993). The riverbank areas of a town are often considered to be attractive from the tourism and recreational point of view. In urban space the flowing river often has an influence on tourism penetration space, and in some cases colonization space. The permanent tourism infrastructure connected with recreation in towns is most often located in attractive areas by the water (LISZEWSKI 1999).

Reservoirs are also built in the middle reaches of some rivers causing changes in the space of the river valley and in its subspaces. Typical for such reservoirs are significant variations in the height of the water surface which cause temporary exposure of a waterlogged surface. This makes them unattractive for recreational tourism but despite these drawbacks there are many such reservoirs where tourism develops not only on the water but also around, mainly due to the lack of alternative natural lakes. Polish examples include the Sulejowski Reservoir on the Pilica, Jeziorsko on the Warta, and Włocławski on the Vistula. Significant changes to the water level create vast waterlogged areas which become an attractive habitat for water birds. These sorts of places are becoming increasingly attractive cognitively and can be regarded as tourism exploration space. An example here is the Jeziorsko Reservoir with an official 'silence' zone in order to protect the breeding sites of water birds.

The penultimate stage of the valley, analysed in terms of river valley tourism space development, is the lower river course. It usually has a very wide and shallow valley cross section which smoothly rises to higher ground. The river here flows in a large and wide bed, the water drop is small, and access to water from the banks is usually easy while the valley landscape is 
wody $\mathrm{z}$ brzegu przeważnie nie jest utrudniony. Krajobraz przyrodniczy doliny $\mathrm{w}$ jej dolnym biegu jest raczej mało urozmaicony, monotonny i otwarty. Natomiast szeroka, rozległa dolina „wydobywa” i podkreśla w krajobrazie obiekty położone na wysoczyźnie tuż przy krawędzi doliny. Szczególnie interesująco wyglądają panoramy miast nadrzecznych oglądane od strony rzeki. W Polsce tego typu krajobraz można podziwiać np. w dolinie Wisły, a za granicą Loary (słynne zamki położone nad jej brzegami). Poza atrakcyjnym krajobrazem dolnego biegu rzeki, znaczna jej szerokość i odpowiednia głębokość koryta sprzyja rozwojowi żeglugi śródlądowej, umożliwiając poruszanie się nawet większymi jednostkami pływającymi. W dolnej części doliny rzeki, podobnie jak w jej górnym i środkowym biegu, mamy do czynienia z przestrzenią penetracji turystycznej.

Szerokie i plaskie dno doliny, wraz z okresowo zalewaną terasą zalewowa, stanowi utrudnienie dla rozwoju form stakego zagospodarowania turystycznego bezpośrednio nad brzegami ${ }^{5}$. Występuje ono raczej w dalszej odległości od rzeki, głównie na terasach nadzalewowych i na wysoczyźnie, choć obserwuje się do dziś przykłady niewłaściwej lokalizacji obiektów turystycznych na terasie zalewowej.

Ostatnim elementem złożonego systemu przyrodniczo-gospodarczego doliny rzecznej jest ujście, czyli miejsce, gdzie rzeki kończą swój bieg wpadając do morza lub jeziora. Wyróżnia się dwa typy ujść rzecznych. Pierwszy z nich to delta, powstaje kiedy rzeka uchodzi kilkoma odnogami, a cały obszar ujścia jest płaski i ma charakter bagienny. Drugim typem jest ujście lejkowe ${ }^{6}$, co oznacza, że rzeka bezpośrednio wpływa do akwenu poszerzoną i głęboką doliną. Cechą charakterystyczną ujść rzecznych z punktu widzenia rozwoju turystyki jest ich położenie blisko morza lub jeziora. Sytuacja taka stwarza dogodne warunki do rozwoju turystyki i sportów wodnych związanych $\mathrm{z}$ jednym i drugim rodzajem środowiska wodnego. Czasami traktuje się rzeki jako ,przedłużenie morza" i odwrotnie, morze jako ,przedłużenie rzek” (KURNATOWSKI 1998). W przypadku obydwu rodzajów ujść rzeki mamy do czynienia przede wszystkim z przestrzenią penetracji turystycznej. Ujścia deltowe rzek sprzyjają raczej penetracji o charakterze poznawczym, w odróżnieniu od ujścia lejkowatego, gdzie istnieją dogodne warunki do rozwoju żeglarstwa i innych sportów wodnych. Delty rzek są interesującymi obszarami przede wszystkim z przyrodniczego punktu widzenia. Ze względu na wartości środowiska naturalnego są one często objęte różnego rodzaju formami jego rather monotonous and open. The panoramas of river valley settlements seen from the river look particularly interesting, in Poland this kind of landscape can be admired for instance in the Vistula and abroad on the Loire with its famous castles. Apart from the attractive landscape, the width and depth of the river are conducive to the development of inland navigation and make it possible to use larger vessels. In this part of the river valley there is tourism penetration space as in the upper and middle reaches.

The wide and flat valley floor, together with its periodically flooded flood plain, hinders the development of a permanent tourism infrastructure directly on the river banks ${ }^{5}$. This appears further from the river, mainly on terraces and on the higher areas, although poorly located tourism infrastructure can also be found.

The last element of the complex natural-economic system of the river valley is the mouth i.e. where the river flows into a sea or lake. There are two types of mouths. The first is a delta where the river terminates in the sea or lake via several distributaries and the whole area is flat and marshy. The other type is the estuary6 which means that the river flows in a widened and deeper valley directly into the sea. From the point of view of tourism development, a characteristic feature of river mouths is their location close to the sea or lake. This situation offers good conditions for the development of tourism and water sports, typical for both kinds of water environment. Sometimes rivers are treated as a 'sea extension' and the other way round - the sea as a 'river extension' (KURNATOWSKI 1998). In both types of mouths above all there is tourism penetration space. Deltas are conducive to cognitive penetration, while the estuaries are better for sailing and other water sports. River deltas are very interesting as far as the natural world is concerned and they are often protected by law (e.g. the national parks of the Danube and the Rhone deltas). The human economy connected with water 
ochrony, np. parki narodowe delty Dunaju czy Rodanu (park regionalny Camarque). Gospodarka człowieka związana $\mathrm{z}$ regulacją stosunków wodnych na podmokłych obszarach deltowych stworzyła interesujący krajobraz kulturowy, stanowiący także atrakcję turystyczną. Przykładem może tu być delta Wisły i położone w jej obrębie Żuławy Wiślane.

Atrakcyjność turystyczna ujść rzecznych może także być wynikiem emocjonalnego stosunku człowieka do tego rodzaju miejsc. Przez analogię do źródeł, w których „,cos”” się zaczyna, ujście rzeki jest miejscem, gdzie „coś” się kończy i fakt przebywania w takim miejscu może wywoływać określone emocje. W tym sensie obszar ujścia rzeki może być traktowany jako przestrzeń eksploracji turystycznej.

W charakterystyce poszczególnych typów funkcjonalnych została pominięta przestrzeń urbanizacji turystycznej ${ }^{7}$. Może się ona bowiem pojawić w przestrzeni doliny rzeki wszędzie tam, gdzie występuje, poprzedzająca urbanizację, przestrzenią kolonizacji turystycznej. Duży popyt na czyste i nieprzekształcone środowisko jest obecnie istotną determinantą rozwoju osadnictwa. Doliny rzek mają właśnie do zaoferowania możliwości zamieszkania w czystym i niezmienionym środowisku, choć $\mathrm{z}$ drugiej strony stwarzają zagrożenia powodziami. Wobec tego nadrzeczna przestrzeń urbanizacji turystycznej może rozwijać się głównie na obszarach położonych co najmniej na wysokości terasy nadzalewowej i na wysoczyźnie, gdzie zagrożenie powodziowe jest najmniejsze.

Podsumowaniem rozważań na temat nadrzecznej przestrzeni turystycznej jest tab. I, w której zprezentowano jej zróżnicowanie funkcjonalne

T a b e Ia I. Nadrzeczna przestrzeń turystyczna - układ doliny wzdłuż biegu rzeki

\begin{tabular}{|l|c|c|c|c|c|}
\hline \multirow{2}{*}{$\begin{array}{c}\text { Bieg rzeki } \\
\text { - odcinek }\end{array}$} & \multicolumn{5}{|c|}{ Typy przestrzeni turystycznej } \\
\cline { 2 - 6 } & eksploracji & penetracji & asymilacji & kolonizacji & urbanizacji \\
\hline Źródła & $\sqrt{ }$ & - & - & - & - \\
\hline Górny & - & $\sqrt{ }$ & $\sqrt{ }$ & $\sqrt{ }$ & - \\
\hline Srodkowy & $\sqrt{ }$ & $\sqrt{ }$ & $\sqrt{ }$ & $\sqrt{ }$ & - \\
\hline Dolny & - & $\sqrt{ }$ & $\sqrt{ }$ & $\sqrt{ }$ & - \\
\hline Ujście & $\sqrt{ }$ & $\sqrt{ }$ & - & - & - \\
\hline
\end{tabular}

$\sqrt{ }$ - największe znaczenie fragmentu przestrzeni doliny rzeki dla rozwoju danego typu przestrzeni turystycznej.

$\sqrt{ }, \sqrt{ }$ - mniejsze znaczenie fragmentu przestrzeni doliny rzeki dla rozwoju danego typu przestrzeni turystycznej. regulation on water-logged delta areas creates an interesting cultural landscape which is another tourism attraction (e.g. the Vistula delta and Żuławy).

Tourism attractiveness may result from man's emotional attitude to these kinds of places and similar to a river source where 'something' begins, the river mouth is a place where 'something' ends and staying there may evoke particular emotions. In this sense the river mouth may be treated as tourism exploration space.

The description of individual func-tional types did not include tourism urbanization space? This may be found in all those parts of the river valley space where tourism colonization space is found. A great demand for clean and unchanged environment is currently an important determinant of settlement development and river valleys can offer such an environment, although on the other hand there is also a risk of flooding. Therefore, river valley tourism urbanization space can develop mainly on areas situated at least at the height of the terraces and on the upland, where the risk of flooding is least.

Table I summarizes the discussion of river valley tourism space and presents the functional differentiation of this space (mostly tourism penetration space) which results from the longitudinal shape of the river and its valley.

T a b I e I. River valley tourism space - Iongitudinal section

\begin{tabular}{|l|c|c|c|c|c|}
\hline \multirow{2}{*}{$\begin{array}{c}\text { River valley } \\
\text { space }\end{array}$} & \multicolumn{5}{|c|}{ Types of tourism space } \\
\cline { 2 - 6 } & $\begin{array}{c}\text { explora- } \\
\text { tion }\end{array}$ & $\begin{array}{c}\text { penetra- } \\
\text { tion }\end{array}$ & $\begin{array}{c}\text { assimila- } \\
\text { tion }\end{array}$ & $\begin{array}{c}\text { coloniza- } \\
\text { tion }\end{array}$ & $\begin{array}{c}\text { urbaniza- } \\
\text { tion }\end{array}$ \\
\hline Sources & $\sqrt{ }$ & - & - & - & - \\
\hline Upper & - & $\sqrt{ }$ & $\sqrt{ }$ & $\sqrt{ }$ & - \\
\hline Middle & $\sqrt{ }$ & $\sqrt{ }$ & $\sqrt{ }$ & $\sqrt{ }$ & - \\
\hline Lower & - & $\sqrt{ }$ & $\sqrt{ }$ & $\sqrt{ }$ & - \\
\hline Mouth & $\sqrt{ }$ & $\sqrt{ }$ & - & - & - \\
\hline
\end{tabular}

$\sqrt{ }$ - greater importance for the development of a given type of tourism space.

$\sqrt{ }, \sqrt{ }$ - lesser importance for the development of a given type of tourism space.

Sou r ce: Author. 
wzdłuż biegu rzeki. $Z$ tabeli wynika, że nadrzeczna przestrzeń turystyczna przede wszystkim reprezentowana jest niemal na całej długości rzeki przez typ przestrzeni penetracji turystycznej, co wynika z pasmowego charakteru układu rzeka-dolina.

Nadrzeczną przestrzeń turystyczną można także opisać w układzie poprzecznym doliny (tab. II), gdzie dno doliny, które składa się z koryta wypełnionego woda oraz terasy zalewowej, to przede wszystkim przestrzeń penetracji turystycznej. Turystyka w tej części doliny jest realizowana głównie na rzece, w mniejszym stopniu wzdhuż jej brzegów. Sama rzeka może być także rozpatrywana jako miejsce eksploracji turystycznej. Wyraźny podział doliny przez rzekę na dwie części powoduje, że przeciwległe brzegi postrzegane są jako tereny bardziej interesujące i nie do końca odkryte. Ciekawość i chęć odkrywania tego, co znajduje się na drugim, mniej dostępnym brzegu, jest jedną $\mathrm{z}$ determinant związanych ze specyfiką poprzecznego układu doliny rzecznej wpływających na rozwój turystyki. Występowanie wody i terenów zalewowych na dnie doliny powoduje, że nie powstają tu formy trwałego zagospodarowania turystycznego, które świadczyłyby o istnieniu przestrzeni kolonizacji turystycznej ${ }^{8}$. Sytuacja taka występuje zwykle w przypadku, kiedy rzeka płynie naturalnym korytem i jest nieuregulowana. Tam, gdzie rzeki są uregulowane, np. na terenach miejskich, brzegi rzeki mogą być trwale zagospodarowane, także i infrastrukturą turystyczną umożliwiającą realizację różnych form turystyki i rekreacji związanych $\mathrm{z}$ woda.

T a b e Ia II. Nadrzeczna przestrzeń turystyczna - układ poprzeczny doliny

\begin{tabular}{|c|c|c|c|c|c|}
\hline \multirow{3}{*}{$\begin{array}{c}\text { Typy } \\
\text { przestrzeni } \\
\text { turystycznej }\end{array}$} & \multicolumn{5}{|c|}{ Przestrzeń doliny rzeki } \\
\hline & \multicolumn{2}{|c|}{ dno } & \multirow[b]{2}{*}{$\begin{array}{c}\text { terasy } \\
\text { nadzalewowe }\end{array}$} & \multirow[b]{2}{*}{ stok } & \multirow[b]{2}{*}{$\begin{array}{l}\text { krawędżl } \\
\text { wysoczyzna }\end{array}$} \\
\hline & $\begin{array}{l}\text { koryto } \\
\text { rzekil } \\
\text { rzeka }\end{array}$ & $\begin{array}{c}\text { terasa } \\
\text { zalewowa }\end{array}$ & & & \\
\hline Eksploracji & $\sqrt{ }$ & - & - & - & - \\
\hline Penetracji & $\sqrt{ }$ & $\sqrt{ }$ & $\sqrt{ }$ & $\sqrt{ }$ & $\sqrt{ }$ \\
\hline Asymilacji & - & - & $\sqrt{ }$ & - & $\sqrt{ }$ \\
\hline Kolonizacji & - & $\sqrt{ }$ & $\sqrt{ }$ & - & $\sqrt{ }$ \\
\hline Urbanizacji & - & - & - & - & - \\
\hline
\end{tabular}

$\sqrt{ }$ - największe znaczenie fragmentu przestrzeni doliny rzeki dla rozwoju danego typu przestrzeni turystycznej.

$\sqrt{ }, \sqrt{ }$ - mniejsze znaczenie fragmentu przestrzeni doliny rzeki dla rozwoju danego typu przestrzeni turystycznej.

Ż ród lo: Opracowanie własne.
River valley tourism space can also be described in cross-section (table II) where the river channel filled with water and the flood-plain form above all tourism penetration space. Tourism in this part of the valley is found mainly on the river and, to a smaller extent, along its banks. The river itself may also be regarded as a tourism exploration site. The clear division of the valley into two parts creates the impression that the opposite bank is more interesting and not explored to the end. Curiosity and the willingness to discover what is on the other, less accessible bank, is one of the tourism factors connected with the special character of the cross-section of the river valley. The river and the flood-plain on the valley floor prevent forms of permanent tourism infrastructure from appearing which might demonstrate the existence of tourism colonization space . $^{8}$ Such is the situation when the river flows unregulated within a natural channel. The banks of regulated rivers, e.g. in urban areas, may be permanently developed and including tourism infrastructure which makes different forms of water tourism and recreation possible.

T a b I e II. River valley tourism space - valley cross-section

\begin{tabular}{|c|c|c|c|c|c|}
\hline \multirow{3}{*}{$\begin{array}{c}\text { Types } \\
\text { of tourism } \\
\text { space }\end{array}$} & \multicolumn{5}{|c|}{ River valley space } \\
\hline & \multicolumn{2}{|c|}{ valley floor } & \multirow[b]{2}{*}{ terraces } & \multirow[b]{2}{*}{ slope } & \multirow[b]{2}{*}{$\begin{array}{l}\text { surrounding } \\
\text { hills }\end{array}$} \\
\hline & $\begin{array}{c}\text { river } \\
\text { channel } \\
\text { river }\end{array}$ & $\begin{array}{l}\text { flood } \\
\text { plain }\end{array}$ & & & \\
\hline Exploration & $\sqrt{ }$ & - & - & - & - \\
\hline Penetration & $\sqrt{ }$ & $\sqrt{ }$ & $\sqrt{ }$ & $\sqrt{ }$ & $\sqrt{ }$ \\
\hline Assimilation & - & - & $\sqrt{ }$ & - & $\sqrt{ }$ \\
\hline Colonization & - & $\sqrt{ }$ & $\sqrt{ }$ & - & $\sqrt{ }$ \\
\hline Urbanization & - & - & - & - & - \\
\hline
\end{tabular}

$\sqrt{ }$ - greater importance for the development of a given type of tourism space.

$\sqrt{ }, \sqrt{ }$ - lesser importance for the development of a given type of tourism space.

Source: Author. 
Nad dnem doliny rozciagają się terasy nadzalewowe. Są to obszary położone najbliżej rzeki, nadające się do trwałego zagospodarowania turystycznego. Terasy nadzalewowe są miejscem rozwoju trzech typów przestrzeni turystycznej: penetracji, asymilacji i kolonizacji. Ich wielkość i zakres będą zależały przede wszystkim od wielkości rzeki i stopnia rozwinięcia $\mathrm{w}$ dolinie poszczególnych poziomów terasowych.

Następnym fragmentem poprzecznego przekroju doliny jest stok, który mniej nadaje się do lokalizacji trwałych form zagospodarowania turystycznego. Ze względu na nachylenie terenu utrudniona może być także penetracja turystyczna po stoku wzdłuż doliny. Stąd stoki mają mniejsze znaczenie w rozwoju nadrzecznej przestrzeni turystycznej.

Warunki przyrodnicze $\mathrm{w}$ dolinie rzecznej zmieniają się w miejscu przejścia stoku w strefę krawędziową doliny i wysoczyznę. Pod względem ukształtowania tereny te wyraźnie kontrastują z najbliższym otoczeniem. Wyrazistość rzeźby w strefie krawędziowej doliny stanowi o walorach krajobrazowych obszaru, przez który przepływa rzeka, przez co czyni go atrakcyjnym dla turystyki wędrownej. Na wysoczyźnie zwykle nie spotyka się stałych większych naturalnych barier, które utrudniałyby rozwój trwałych form zagospodarowania turystycznego. Większa odległość od rzeki powoduje, że tereny te są mniej atrakcyjne dla rozwoju różnych form turystyki związanych z wodą. Najwyżej położone fragmenty doliny rzecznej są więc miejscem, gdzie rozwijają się trzy typy nadrzecznej przestrzeni turystycznej: penetracji, asymilacji i kolonizacji.

Podsumowując należy stwierdzić, że nadrzeczna przestrzeń turystyczna w przekroju poprzecznym doliny charakteryzuje się głównie występowaniem przestrzeni penetracji turystycznej na całej jej szerokości (tab. II). Odpowiada to specyfice warunków przyrodniczych, a zwłaszcza morfologicznych, jakie kreuje rzeka dla rozwoju wszelkich form działalności człowieka, w tym także turystyki i rekreacji.

Opisane w pracy relacje pomiędzy rzeką $i$ jej doliną a turystyka, których efektem jest powstanie i rozwój nadrzecznej przestrzeni turystycznej, z pewnością nie uwzględniają wszystkich możliwych ich aspektów. Odnoszą się one raczej do klasycznego układu fizycznogeograficznego doliny rzeki i mają charakter ogólny oraz schematyczny. Generalnie rzeka i jej dolina tworzą dość wyraźny i bardzo charakterystyczny układ powiązań funkcjonalno-przestrzennych o charakterze przy-
Above the valley floor are terraces which are the land closest to the river and can be used for permanent tourism infrastructure. It is here where three types of tourism space develop: penetration, assimilation and colonization. Their size and extent will depend mainly on the size of the river and on how developed individual terrace levels are in the valley.

The next section of the valley crosssection is the slope which does not lend itself so well to the building of tourism infrastructure. Due to the gradient, tourism penetration on the slope along the valley may also be difficult therefore slopes are of less importance in the development of river valley tourism space.

Natural conditions in the river valley change at the point where the slope changes into the boundary zone between the valley and the upland. This area remains in sharp contrast and the distinctive features of the boundary zone make the landscape very attractive for walking. On the upland natural obstacles which would hinder the development of permanent forms of tourism infrastructure are not usually encountered but a larger distance from the water makes the area less attractive for water tourism. The highest sections of the valley are therefore an area where three types of river valley tourism space develop: penetration, assimilation and colonization.

To sum up, in cross-section river valley tourism space is mostly tourism penetration space (table II). This corresponds to the specific natural, especially morphological, conditions produced by the river for the development of all forms of human activity, including tourism and recreation.

The description of the relations between the river, its valley and tourism, which result in the development of river valley tourism space, certainly does not cover all possible aspects. It concerns rather the classical geographical system of the river valley, and is general and rather schematic. Generally speaking, the rivervalley system is a typical system of 
rodniczo-gospodarczo-społecznym, który wyróżnia się na tle otoczenia. Między innymi $z$ tego powodu przestrzeń doliny rzeki była i nadal jest przedmiotem zainteresowania czlowieka, a turystyka stała się jednym z elementów tego układu. Utworzona w wyniku rozwoju funkcji turystycznej nadrzeczna przestrzeń turystyczna jest zróżnicowana pod względem funkcjonalnym i dostosowana do specyficznych warunków przyrodniczych istniejących na terenie doliny rzeki. Warunki te decydują o rozmieszczeniu, wielkości, zakresie i charakterze poszczególnych typów przestrzeni turystycznej.

\section{PRZYPISY}

'Źródla rzek dość często objęte są ochroną rezerwatową.
${ }^{2}$ Górne odcinki dolin stwarzają najdogodniejsze warunki do budowy sztucznych zbiorników na całej długości rzeki ze względu na niższe koszty związane $\mathrm{z}$ przeznaczeniem pod zbiornik mniejszego obszaru i dużą pojemność wodną.

${ }^{3}$ Sztuczne zbiorniki zatrzymują wiele zanieczyszczeń niesionych przez rzekę, które gromadzą się na dnie zbiornika zarówno w przypadku zanieczyszczeń stałych, jak i w wodzie w przypadku zanieczyszczeń organicznych czy chemicznych.

${ }^{4}$ Szczególnie w tych miejscach doliny, gdzie rzeka meandruje lub tworzy przełom.

${ }^{5}$ Czasami na obszarach ubogich $w$ wody powierzchniowe, gdzie rzeki stanowia jedyny walor wypoczynkowy, trwałe zagospodarowanie turystyczne rozwija się na terenach zalewowych w postaci obiektów noclegowych czy drugich domów budowanych na palach. Tego typu sposoby zagospodarowania turystycznego występują np. w dolnym odcinku doliny Cisy, powyżej Szegedu na Węgrzech.

${ }^{6}$ Aestuarium z lac. - droga morska.

${ }^{7}$ Przestrzeń urbanizacji turystycznej jest to część przestrzeni kolonizacji turystycznej, która staje się obszarem stałego zamieszkania mieszkańców miast (LISZEWSKI 1995).

${ }^{8}$ Patrz przypis 5 . functional-spatial links, showing a distinctive natural-economic-social character. This is one of the reasons why river valley space has always been of interest to man, and tourism has become one of the elements of this system. River valley tourism space, created due to the development of a tourism function, is varied functionally and adapted to the specific natural conditions in the valley determining the distribution, size, extent and character of individual types of tourism space.

\section{FOOTNOTES}

${ }^{1}$ River sources are often protected.

2 The upper parts of valleys make the best conditions for building reservoirs due to the lower cost of covering a smaller area but with a large capacity.

3 A reservoir retains a lot of pollution carried by the river which gathers on the bottom, as well as in the water (organic and chemical pollutants).

${ }^{4}$ Especially in places where the river meanders.

5 Sometimes in areas poor in surface waters where rivers are the only recreational asset, permanent tourist infrastructure develops in floodable areas in the form of hotels or second homes raised on piles. This type of tourism infrastructure can be found in the lower part of the Tisza Valley above Szeged in Hungary.

6 Aestuarium (Lat.) - sea road.

7 Tourism urbanization space is that part of colonization space which has become a permanent residential area for urban inhabitants (LISZEWSKI 1995).

8 See Footnote 5.

\section{BIBLIOGRAFIA - BIBLIOGRAPHY}

CHURSkI, Z., 1998, Loara - przyroda - człowiek, [w:] Rzeki. Kultura - cywilizacja-historia. T. 7, J. Koltuniak (red.), „Śląsk" Sp. z o.o., Katowice, s. 229-251.

Clarke, M., 1996, Kanały Anglii - wczoraj i dziś (Historia i ponowne wykorzystanie zabytków przemysłu), [w:] Rzeki. Kultura - cywilizacja - historia. T. 5. J. Koltuniak (red.), „Slask" Sp. z.o.o., Katowice, s. 107-135.

DEWAILly, J. M., COUdROY DE LILlE, L., LEFORT, I., MONTES, CH., Simon, A., 2005, Recherche d'une méthodologie d'évaluation d'un projet d'aménagement de tourisme fluvial, Etude réalisée dans le carde du programme PREDIT pour le Ministére de l'Equipement, des Transports, du Logement, du Tourisme et de la mer, Institute de Reserches Géographiques. Université Lumiére Lyon 2 , maszynopis.

Drapella-Hermansdorfer, A., 1993, Swiętość rzeki, [w:] Karta kulturowa rzeki. Referaty wygtoszone na sym- pozjum w Rudach 4-5 listopada 1992, G. Bożek (red.), Centrum Dziedzictwa Kulturowego Górnego Ślaska, Katowice, s. 125-128.

DROBEK, W., 1993, Region nadrzeczny - niektóre zagadnienia definicyjne i przestrzenne, [w:] Karta kulturowa rze ki. Referaty wygtoszone na sympozjum $w$ Rudach 4-5 listopada 1992, G. Bożek (red.), Centrum Dziedzictwa Kulturowego Górnego Sląska, Katowice, s. 50-61.

DROBEK, W., 1996, Przestrzeń kulturowa rzeki, [w:] Rzeki Kultura - cywilizacja-historia. T. 3, J. Kołtuniak (red.), „Ślask” Sp. z o.o., Katowice, s. 221-235.

FURGAlA-SElEZNIOW, G., TURKOWSKI, K., NOWAK, A., SKRZYPCZAK, A., Mamcarz, A., 2003, The Ostróda-Elblag Canal - its past and future in aquatic tourism, [w:] Inter national Lake Tourism Conference, T. Härkönen (red.), Publications of the Savonlinna Institute for Regional Development and Research, 5, Finlandia, s. 55-73. 
JACHER, W., 1993, Przestrzeń społeczna rzeki na przykładzie Odry, [w:] Karta kulturowa rzeki. Referaty wygtoszone na sympozjum $w$ Rudach 4-5 listopada 1992, G. Bożek (red.), Centrum Dziedzictwa Kulturowego Gôrnego Slaska, Katowice, s. 45-50.

JALOWIECKI, B., 1998, Przestrzeń społeczna rzek, [w:] Rzeki. Kultura - cywilizacja - historia. T. 7, J. Koltuniak (red.), „Sląsk" Sp. z o.o., Katowice, s. 127-139.

KoRTELAINEN, J., 1999, The river as an actor-network: the Finish forest industry utilization of lake and river systems, Geoforum 20, s. 235-247.

KożUCHOWski, K., 2005, Walory przyrodnicze $w$ turystyce i rekreacji, Wydawnictwo Kurpisz S.A., Poznań, ss. 200.

KuRnatowski, J., 1998, Rzeki sa przedłużeniem morza, [w:] Rzeki. Kultura-cywilizacja-historia. T. 7, J. Koltuniak (red.), „Slask" Sp. z o.o., Katowice, s. 251-275.

LAZZAROTT1, O., 2002, French tourism geographies: a review, Tourism Geographies 4 (2), s. 135-147.

LISZEWSKI, S., BACZWAROW, M., 1998, Istota 1 właściwości przestrzeni rekreacyjno-turystycznej, Turyzm 8, 1, s. $39-63$.

Liszewski, S., 1995, Przestrzeń turystyczna, Turyzm 5, 2 , s. $87-103$.

LiszEWSKI, S., 1999, Przestrzeń turystyczna miasta. (Przykład Lodzi), Turyzm 9, 1, s. 51-71.

LiszeWSKI, S. (red.), 2003, Możliwości i kierunki rozwoju turystyki $w$ dolinie Odry, Łódzkie Towarzystwo Naukowe, Łódź.

Loomis J., Kent P., Strange L., Fausch K., Covich A. 2000 , Measuring the total economic value of restoring ecosystem services in an impaired river basin: results from a contingent valuation survey, Ecological Economics 33, April, s. 103-117.

NoBIS, A., 1996, Założenia „Karty kulturowej rzeki”, [w:] Rzeki. Kultura - cywilizacja - historia. T. 5, J. Koltuniak (red.), „Slask” Sp. z o.o., Katowice, s. 235-251.

PISkozuB, A., 2001, Rzeki w dziejach cywilizacji, Wydawnictwo Adam Marszałek, Toruń, s. 244.

SEWERNLAK, J., 2002, Rzeki a turystyka (zarys problematyki), [w:] Gospodarka turystyczna wobec integracji i rozszerzenia sie Unï Europejskiej, K. Sikora, D. Makillo (red.), Wyższa Pomorska Szkoła Turystyki i Hotelarstwa, Bydgoszcz, s. 87-94.

SMITH, S., 2003, Lake tourism research: themes, practice and prospects, [w:] International Lake Tourism Conference, T. Härkönen (red.), Publications of the Savonlinna Institute for Regional Development and Research, 5, Finlandia, s. 13-25.
SolowIEJ, D., 1992, Podstawy metodyki oceny środowiska przyrodniczego cztouieka, Wydawnictwo Naukowe UAM, Poznań.

STACHOWSKI, J., 1993, O pojmowaniu przestrzeni w geografil turyzmu, Acta Universitatis Nicolai Copernici, Geografia XXVI, Nauki Matematyczno-Przyrodnicze 82, s.171180.

STALSKI, M., 1984, Użytkowanie ziemi w turystyce, Przeglad Zagranicznej Literatury Geograficznej 2, IGiPZ PAN, s. $139-148$.

STEINBACH, J., 1995, River related tourism in Europe - an overview, GeoJournal, 35.4, s. 443-458.

SZCZEPAŃSKI, M. S., 1993, Socjologia przestrzeni 1 przestrzeń kulturowa rzeki, [w:] Karta kulturowa rzeki. Referaty wygtoszone na sympozjum $w$ Rudach 4-5 listopada 1992, G. Bożek (red.), Centrum Dziedzictwa Kulturowego Górnego Slaska, Katowice, s. 25-38.

TuOHINO, A., 2003, Lakes as an opportunity for tourism marketing, [w:] International Lake Tourism Conference, T. Härkönen (red.), Publications of the Savonlinna Institute for Regional Development and Research, 5, Finlandia, s. 305-313.

WARSZYṄSKA, J., JACKOWSKI, A., 1978, Podstawy geografï turyzmu, PWN, Warszawa.

WASOwICZ, E., 2004, Produkt turystyczny i jego jakość, [w:] Markowe produkty turystyczne, A. Panasiuk (red.), Wydawnictwo Uniwersytetu Szczecińskiego, s. 169-178.

WECŁAWOWICZ-BILSKA, E., 1993, Kilka przykładów zagospodarowania dolin rzek $i$ ich zlewni $z$ punktu widzenia ochrony istniejacych zasobów kulturowych, [w:] Karta kulturowa rzeki. Referaty wygtoszone na sympozjum $w$ Rudach 4-5 listopada 1992, G. Bożek (red.), Centrum Dziedzictwa Kulturowego Górnego Śląska, Katowice, s. $129-141$.

WiLuS, R., 1997, Rozwój funkcji turystycznej $w$ dolinie rzeki Warty na odcinku od Dziatoszyna do Uniejowa, „Szlakami Nauki” 24, Łódzkie Towarzystwo Naukowe, Łódź, ss. 216.

WŁodARCZYK, B., 1999, Przemiany form aktywności turystycz nej. Przykład krawędzi Wyżyny Łódzkiej, „Szlakami Nauki" 29, Łódzkie Towarzystwo Naukowe, Łódź, ss. 194.

WOJCIECHOWSKA, J., 1998, Kolonizacja turystyczna terenów nadpilicznych, „Szlakami Nauki” 28, Łódzkie Towarzystwo Naukowe, Łódź.

WYRZYKOWSKI, J., 1994, Rzeki jako przedmiot zainteresowań turystycznych (na przykładzie Polski), [w:] Rzeki. Kultura - cywilizacja - historia. T. 3, J. Kołtuniak (red.), „Sląsk" Sp. z o.o., Katowice, s. 157-171. 